\title{
REMARKS ON THE CHURCH IN THE CONSUMER SOCIETY: SIMILARITIES AND DISSIMILARITIES
}

\author{
L.O.K. Lategan ${ }^{1}$
}

\begin{abstract}
The church cannot escape the influence of the consumer society. The influence of the consumer society is often viewed as negative although it can have many positive influences on the building and growth of the church. The consumer society reminds the church that, although the message of the church cannot change, the style of church services can. Pastors should make it clear that the gospel message is not a product for sale; however the gospel message should be directed at the needs of people. This article outlines the influence of the consumer society on the church. The article also outlines the similarities and dissimilarities between the church and the consumer society. It concludes with guidelines on how the church can bring its gospel message regardless the dominant influences of the consumer society.
\end{abstract}

\section{OPSOMMING}

Die kerk kan nie aan die invloed van die verbruikersamelewing ontkom nie. Dikwels word die invloed van die verbuikersamelewing negatief beoordeel, terwyl dit juis 'n positiewe uitwerking op kerkopbou kan hê. Die verbuikersamelewing maak die kerk daarvan bewus dat, alhoewel die boodskap van die evangelie nie kan verander nie, dit noodsaaklik is dat die manier waarop die evangelie bedien word, aangepas sal word vir bepaalde omstandighede. Hier kan lesse van die verbruikersamelewing geleer word. Predikante moet dit duidelik mak dat die evangelie nooit as 'n winkelproduk hanteer kan word nie, maar die aanbieding van die evangelie moet gerig wees op die omstandighede en behoeftes van lidmate. Hierdie artikel wys op die invloed van die verbuikersamelewing op die kerk, parallelle wat tussen die verbruikersameling en die manier hoe die kerk steeds die uniekheid van sy boodskap kan oordra te midde van 'n aanwesige verbuikersmoraal, getrek kan word — ook by kerklidmate.

1 Prof. L.O.K. Lategan, Dean: Research and Development, Central University of Technology, Free State, Private Bag X20539, Bloemfontein 9300. E-mail: llategan@tfs.ac.za 


\section{GENERAL OBSERVATIONS}

\subsection{Product and services are inseparable}

In business the concept of the customer is of paramount importance. The customer is so powerful that even the product is superseded. In a competitive market, companies realise that the customers are the most important assets to any company. Through once-off big spenders or returning small spenders, companies remain in business. Customers return for more reasons than only high quality products at competitive prices. Customers value the way in which they are treated. Customers can also change their taste in available products - they can become dissatisfied with a business' product and services. Robbins, Bergman, Stagg and Coulter (2003:83) rightfully remark that "Customers obviously represent potential uncertainty to an organisation." The valuable lesson to be learnt is that companies can never own a customer, but they can possess the customer relationship (Dhar \& Glazer 2003:8692). This means that a company can have the business of the customer in the bank provided that the product and the service satisfy the customer's needs. It should be noted that product and service are like the proverbial horse and carriage — you can't have one without the other!

\subsection{The church is assessed for its product and services}

Lately, there has been a movement to contextualise the church within the consumer society. Questions are raised on the effectiveness of the church's product and services. The consumer society asks the question whether the customers (read "congregation") receive value for money (read "a good sermon/pastoral care"). Does the congregation transfer the church sermon into daily life? If the answer is "yes", how does the congregation "consume" the Bible, sacraments, pastoral care, etc. in its (the congregation's) daily life? Are church sermons at all consumable? Do Christian life and values still prevail? These and many similar questions are evidence of a customer-oriented view of the church.

Although one may wish to differ from this view, the fact that the church is being compared to a shopping mall cannot be ignored. People "shop" around to find the "best" church that will satisfy their religious/ 
pastoral needs. Spirituality is more important than confession; religious experience replaces structured sermons; pastoral care employs techniques beyond the Bible and theological foundations; neighbourly love and spiritual security straddle commands and religious instructions. People believe, but not in the traditional (confessional) manner. Koinonia and diakonia have a humanistic foundation and no religious roots. This situation is confirmed by two recent studies: Nel (2003) writes on people's search for God detached from ecclesiastical borders and Van Niekerk (1998) analyses the church in a changing culture. From these studies it is obvious that although religion and church are closely related the church is perceived as institutional and becoming less important in people's religious practice. To understand the societal role of the church, it (the church) cannot be understood as detached or apart from societal developments. This phenomenon is not new, however. Burger (1995) writes about an adoptive ministry in a time when the church has to reposition itself due to change. This cannot be easy since the church — itself a complex institution - has to address the religious challenges of a changing culture which, in return, is complex in itself. It will therefore come as no surprise that positioning a church in a changing culture can be compared to a culture shock. The congregation is very often left with feelings of confusion, disorientation and emotional confusion caused by being plunged into a new culture (Robbins et al. 2003:126). The congregation is very often left with the distrustful question: Why I am still a member of the church?

In return, the church as an institution has also to reconsider its role in the market place. McIntosch (2002) rightfully points out that the size of the church determines the style of events. The message is simple: no two churches are alike and should be managed accordingly. Following this observation is the consumer society principle that size and the style of events are inseparable. A small congregation cannot be managed in a similar way as a mega size church. 


\section{BRIEF OF THE ARTICLE}

This article will argue that to take the church forward in meeting the challenges of a post-modern society, the impact of consumer society cannot be ignored. Although consumer society might view the church as another shopping mall, the valuable lesson to be learnt is that the church can learn from consumer society how to deliver its product (religious services and pastoral care) and how to service its congregation (customers). The article will support the view that church renewal cannot ignore the experience of consumer society; yet where businesses should compromise on their products to secure a returning clientele, the church can never compromise on the contents of its message (read "its product"). Although the contents may not be tampered with, however, the package of the product should change to meet a diverse community of believers.

\section{CONTEXTUALISATION: THE CHURCH AS A SHOPPING MALL}

It cannot be ignored that the church is continuously subjected to the assessment of consumer society. For example, during church services the question is frequently asked as to whether the church communities are geared to meet the needs of a changing society. This question and its particular vocabulary are typical of the language used by consumer society (see Robbins et al. 2003).

Concerns that the role of the church in society is declining are evident on agendas of church synods. In general three questions are asked:

- How does the church address a profit-driven, supply and demand culture?

- Why do people prefer worship outside the official church structures?

- How does the church compete with semi-religious institutions and practices to keep the attention of the parish?

These questions are confirmed by the following grassroots level debate:

- Van Zyl (2003) reports that church migration is the order of the day. The heyday of church loyalty has passed. People attend a church 
where they feel comfortable and where their needs are addressed. Although the church is God's creation, it cannot be ignored that the church has a social dimension that appeals to people. Even from the early history of the church, it has always been evident that the church makes a difference in the daily lives of ordinary people.

- In a pastoral address to his congregation, the Rev. Bertie Haasbroek (2003) argued that the church would become irrelevant unless it changed the lives of people. He sees this as the actual assignment of the church. It is a task that is easier said than done, though. The church has to deal with individual egos that are more important than the core mission of the church. For the church to change the lives of people two things are important. Firstly, the church should take the changing environment seriously. Secondly, it should recognise the way in which people experience life and offer them church services accordingly.

- Buitendag (2003) says that the church has to ask two questions. Firstly how would the church like to be? Secondly how does the world perceive the church to be? For the former a strategic planning exercise is necessary and for the latter a communications audit.

What can be learnt from these questions and observations is that the church has to compete for the attention of its parish with other societal institutions. People find security in science, art, culture, gymnasiums, psychologists, etc. in the belief that these things will provide them with pastoral care. Science, art, culture, gymnasiums, psychology and so on are well known for the fact that they provide a form of security for people. Visagie (1986:33) and Piët (2003) comment on this, when they say that people find their salvation within their experience of reality. Science, technology and the economy have become invaluable aspects of human existence and security.

This conceptualisation underlines the fact that the church cannot isolate itself from consumer society. It is also obvious that in serving its parish, the church should understand consumer society, as well as the church's position within consumer society. The next section will elucidate this matter further. 


\section{APPLYING CORE CHARACTERISTICS OF CONSUMER SOCIETY TO THE CHURCH}

The examples mentioned above emphasise that the church cannot escape the drift towards a new consumer-driven philosophy. Ensuing from this observation is the question "How do the core characteristics of consumer society apply to the church?" The following should be pointed out in this regard:

\subsection{The client should have an experience ("happening")}

Shopping is not the main event, the activities associated with shopping are. Piët (2003) refers to this as the access economy. For example: family restaurants offer much more than just an affordable menu. They include attractions such as play stations for children, so that while the adults enjoy their food, the children can amuse themselves. The competitive edge of business is no longer built around the product, but around the value that can be added to the product. This refers to the so-called "experience economy." Piët (2003) defines this economy as the products and services directed at the emotional needs of the individual and/or group.

Applying this kind of philosophy to the church, we could say that people are seeking something more than simply the church ceremony. A community of faith would like to experience their faith through cell groups, Bible study groups, song and praise services, etc. The move to "spirituality" is evidence of this need (see Van der Merwe [1995], Nicol [1989]). No critique can be brought in against the need of people to "experience their faith", since this should be at the core of life before God (coram Deo).

It should be emphasised, therefore, that the church has something to learn from consumer society about experiencing things. Experience is an important issue in human existence and cannot be isolated from religion. In the past, experience of faith has been associated (negatively) with the charismatic churches only — as if someone from a reformed background cannot/should not experience faith at all. Paul's letter to the Philippians is a good example of how people can rejoice in the Lord. If people trust in the Lord, they should experience their joy in the Lord daily. 
4.2 Companies shift their focus from the product to the customer

A church can learn from this shift in focus that people are important in building a community of faith. The "product" (read "gospel") cannot be adapted to suit people, but it can be presented in such a way that it appeals to people. To give a concrete example: different preaching styles appeal to different groups of people. It would be foolish if the ministry did not concentrate on the youth if the youth forms the majority of the congregation. There is no point in sustaining a specific ministry if it does not appeal to the congregation at all. When a church is adapting its style and approach to meet the needs/expectations of the congregation, it does not mean that the gospel has to be compromised at all. The Christian doctrine is all about a new lifestyle in the kingdom of God, the belief in eternal life and the profession of the Trinity.

It is imperative that this concept be clearly understood: when the approach to the ministry changes, it does not mean that this changes the gospel. Product and presentation are two separate issues. No product is designed to meet the presentation thereof. The presentation of the product follows the product and not the other way around.

This marketing concept can be translated to the context of the church. The product is the gospel and the presentation/package of the product consists of the religious sermons and activities. As time progresses, people have different needs that should be attended to. A perfect example of this is the shift away from rationalism to irrationalism. For many years congregations had a rationalistic understanding of faith and religion. For no logical reason the public profession or affirmation of faith was linked to an age and not to maturity in faith. Conveniently the parish called on the Heidelberg Catechism, which refers to faith as knowledge and trust. The emphasis, however, was on knowledge. Currently the irrationalistic approach is on spirituality - a trend that supersedes knowledge. In sermons the focus is very often on experiencing faith instead of understanding it. Liturgical elements such as prayer, music, silence, etc. contribute to the irrationalistic understanding of faith. 


\subsection{Products should have a particular brand}

The global economy has cut prices to the bone. Through e-shopping people can buy the cheapest/highest quality product regardless of its country of origin. To maintain a competitive advantage in the market place companies are competing by means of their brand names. A brand name is the unique feature of a product, distinguishing one product from another. Brand-name awareness is growing in consumer society. One of the best examples is the "No Name" brands of Pick 'n Pay. When it was reported that some food lines in the "No Name" range were poisoned, there was no remarkable effect on its food retail due to the trust that the shoppers had in the "No Name" brand. In the Sunday Times (3 August 2003) the following advertisement was published:

The good news is that now we can reintroduce those product lines that had been withdrawn from our shelves, and return to business. For your safety, permanent changes to our security measures in store have been made.

Successful brands succeed because of what they stand for and not how they perform. Symbolism is therefore important. These brands are becoming icons because through these brands people experience powerful myths. By "myth" we mean simple stories that people can relate to and that can help them relieve their tensions (Holt 2003).

Applied to the church, we can say that churches should also "brand" their church ceremonies. We cannot deny the fact that a religious community is characterised by its specific features. An example of church branding is the profession of faith. The profession, or confirmation, of faith depicts the uniqueness of a congregation. Contrary to popular practices, professions of faith should not be limited to theoretical constructs but should be the framework for church ministry. A reformed character differs from a catholic one. Professions of faith can direct the church's character and guide the congregation on the roots of a particular church. A declining profession of faith will lead to total confusion on issues such as baptism, the Lord's supper, marriage, etc.

\subsection{Lessons learnt}

From these characteristics, it is obvious that consumerism is a dominating feature - even in religious life. No congregation can afford 
to turn a blind eye to the influence of consumerism on religious life. Consumerism should, however, be understood in context.

The positive influence of consumerism is that it opens our eyes to the advantages that consumerism holds for revitalising churches and church activities. In line with this, writes Gouws (2003), the branding of the church is quality theology and true love. These characteristics should be found once more in all church activities.

The negative influence is the dominating effect of consumerism. In the context of ideology critique, consumerism may be classified as an ideology. Visagie's (1990) definition relates to the way in which ideology is meant to be understood in this article. He defines ideology as a premise taken from reality, which dominates man's understanding/experiencing of reality. If this definition is applied to consumer society then it can be argued that the customer experience determines all other societal relationships. The problem with an ideology is therefore its dominating power and control it has over the customer. Within the context of religious life, this is not acceptable. The discussion of the core business of the church in the next section will substantiate this remark.

\section{THE CORE BUSINESS OF THE CHURCH}

Faith is the core business of the church. This means that the church as a community of believers should grow in their relationship with God (internal core business). In this relationship it is all about the lifestyle in the presence of the living God (coram Deo). This relationship is augmented through church ceremonies, pastoral care, etc. In addition, the church has the responsibility to take its core business beyond the borders of the church (into missionary work, for instance).

The statement that faith is the core business of the church can be substantiated by various metaphors for the church: the vineyard and the shoot (John 15); the body of Christ (1 Cor. 12:14vv.); the bride of Christ (Revelations 9, 17), etc. Based on these metaphors, Reformed Theology defines the church as a community of believers. This community expresses the close relationship with God. Tolmie (1991:70) \& Velema (1996) say that these metaphors highlight the following important characteristics of the church: 
- The church is closely associated with Christ.

- The church as body of Christ underpins the idea that there is also a close relationship between the body of believers.

- The church is characterised by the righteous acts of the community of faith.

- The church should be characterised by joy and hope as it is en route to the second coming of Christ.

What is important in a consumer society is to contextualise the core business of the church in the context thereof. A valuable hint is that of Van Zyl (2003) who remarks that the church is in the advising and service business. "Advice" means that it is only the church which, through preaching, can provide a true vision and reflection of an alternative society - that of God's kingdom. By service we mean that the church should care for people and change their lives positively. Within the context of the church as a body of faith, the church has to advise on faith and to service the faith of people.

Translated into consumer language the following interpretation may be made: the church has to market faith on two levels (not a hierarchical approach): the first level deals with promoting faith as the branding of the Christian religion. At this level it is important to point out the advantages of Christian faith and its associated lifestyle with other religions. At the second level is care for the community of faith (customer care). At this level the parish will stay in a religious community depending on the way in which the church can contribute towards the personal faith and religious growth of the individual (pastoral care).

\section{GUIDELINES: THE CHURCH IN THE CONSUMER SOCIETY}

The consumer society can give valuable direction to the organisation of the church in a post-modern society. The church is not scaled down to a business when its activities are understood in the context of consumerism. The consumer society sensitises the church for a number of issues: 
- The biblical message can never be compromised. However, this message should be contextualised for new situations and emerging needs. The way of doing this should change, not the core business of the church.

- A church member can never be reduced to a client but a church member has the same needs as a customer. A church member's religious and spiritual needs cannot be reduced to the same activity of buying things. But, whether a church member or a client, one's need for quality, change in lifestyle and applicability is the same.

- A customer can complain about a product; a church member can never complain about the gospel. A product is manufactured the gospel is a living idea. A product is based on market research, customers' needs and profitability. The gospel is confessed to be God's Word for his followers. It can either be accepted or rejected.

- A customer can express his/her (dis)satisfaction with the package/ usage of the product; the church member can complain that the church sermons don't address his/her needs. To complain about a church sermon is not to differ with the principle of the Word but with the manner in which the message is communicated to the congregation.

- A customer can return/consume a product, but a church member should live the gospel. The gospel is for free and not a manufactured product. That which is manufactured and bought could be returned for your money back - the gospel cannot be exchanged for something else.

- If the gospel is the "product" and the congregation the "customer" then each one has to be respected for its uniqueness within church life. 


\section{CONCLUSION}

The church cannot ignore the fact that its parish is behaving daily as consumers within the consumer society. Many church members are conditioned to living according to the principles of the consumer society. This situation cannot be ignored by the church. The church should study the changing society and should direct its message to equip its church members to be prepared for the society within which they function. In order to do so, the pastor should equip his parish through sermons, pastoral work and numerous church activities.

\section{BIBLIOGRAPHY}

\section{BUITENDAG J} 2003. Korporatiewe identiteit van die kerk. Kerkbode. 11 July, p. 12.

BURGER C

1995. Gemeentes in transito: vernuwingsgeleenthede in 'n oorgangstyd. Kaapstad: Lux Verbi.

DHAR R \& GLAZER R 2003. Hedging customers. Harvard Business Review. May, pp. 86-92.

\section{Gouws H} 2003. 'n Handelsmerk wat die produk waardig is. Kerkbode. 13 June, p. 10.

\section{HAASBROEK B} 2003. Gaan ons omgewing die kerk verander? Pastoral address to the DRC Universitas, 3 March 2003.

\section{Holt B}

2003. What becomes an icon most? Harvard Business Review. March, pp. 43-49.

\section{McIntosh G L} 2002. One size doesn't fit all. Grand Rapids: Baker Book House.

Nel A

2003. Op soek na God ... buite die kerk? Kaapstad: Lux Verbi. 
NiCOL N

1989. Stem in die stilte: 'n werkboek in Christelike meditasie. Pretoria: Orion.

\section{PIËT S}

2003. De emotie-markt: De toekomst van de beleveniseconomie. Rotterdam: Prentice Hall/Pearson Education Benelux.

\section{Robbins S P, Bergman R, Stagg I \& Coulter M}

2003. Foundations of management. Sydney: Prentice Hall.

\section{TOLMIE D F}

1991. Enkele metafore vir kerkwees in die Nuwe Testament. In: S.D. Snyman $\&$ D.F. Tolmie (reds), ' $n$ Visie van die bediening (Bloemfontein: Pro-Christo), pp. 66-71. UV Teologiese Studies no. 5.

\section{VAN DER MERWE M}

1995. Nuwe treë saam met God. Riglyne en programme oor spiritualiteit en gemeentevernuwing. Cape Town: Lux Verbi.

\section{VAN Niekerk A}

1998. Postmodernisme en NG sending in die Nuwe Suid-Afrika. NGTT 39(4): 367-378.

VAN ZYL H C

2003. Kerklike migrasie: Kerk in advies en diensbesigheid. Volksblad 15 July, p. 6.

\section{VELEMA W H}

1996. Door het Woord bewogen. Leiden: Uitgeverij JJ Groen \& Zoon.

\section{VISAGIE P J}

1986. Versorgende mag. Journal for Christian Scholarship 22(1\&2):32-39.

1990. The mission of the university and the critique of culture. Acta Academica 22(1):114-134.

Keywords

Ministry

Consumer society

Preaching
Trefwoorde

Bediening

Verbruikerskultuut

Prediking 